Acta vet. scand. 1984, 25, 96-106.

From the State Veterinary Serum Laboratory, Copenhagen, Denmark, and Veterinary Research Jaboratory, Department of Agriculture, Dublin, Eire.

\title{
SEROLOGICAL CHARACTERIZATION OF 8 HAEMOPHILUS PLEUROPNEUMONIAE STRAINS AND PROPOSAL OF A NEW SEROTYPE: SEROTYPE 8
}

By

Ragnhild Nielsen and Patrick J. O'Connor

NIELSEN, R. \& P. J. O'CONNOR: Serological characterization of 8 Haemophilus pleuropneumoniae strains and proposal of a new serotype: Serotype 8. Acta vet. scand. 1984, 25, 96-106. - Eight strains of Haemophilus pleuropneumoniae isolated from 8 herd outbreaks of pleuropneumonia in pigs were studied by means of the slide agglutination test, the tube agglutination test, the IHA test and by gel diffusion

The 8 strains were antigenically homogeneous and serologically distinct from serotypes 1 through 7 . It is therefore proposed to refer these strains to a new serotype: serotype 8 , with strain 405 as the type strain.

In addition to the serotype-specific capsular antigens, capsular antigen of serotype 3 (strain 1421) and serotype 6 (strain Fem $\varnothing$ ) could be demonstrated in the 8 strains by means of the IHA test and by gel diffusion analyses.

Haemophilus pleuropneumoniae; serotypes;

indirect haemagglutination test; geldiffusion test; agglutination.

So far, 7 serotypes of Haemophilus pleuropneumoniae have been established.

By agglutination and cross absorption tests Nicolet (1971) $\mathrm{d}$ :fferentiated serotypes 1, 2 and 3 . This serological scheme has later been extended with serotypes 4 and 5 (Gunnarsson et al. 1977), serotype 6 (Nielsen 1982) and serotype 7 (Rosendal \& Boyd 1982).

Recently a hitherto unrecognized serotype was isolated from 
Irish and Danish outbreaks of pleuropneumonia in pigs. The present study describes the isolated strains and their serological properties.

\section{MATERIAL AND METHODS}

Two Irish (strain 312 and 405) and 6 Danish strains (E.J. 84, $925,1265,9436,13546$ ) from 8 herd outbreaks of pleuropneumonia were examined. The cultural and biochemical characteristics of the strains were consistent with earlier descriptions of H. pleuropneumoniae (Kilian 1976, Biberstein et al. 1977, Nielsen 1982 ). Reference strains representing serotypes 1 through 7 were: Shope 4071, S 1536, S 1421, M 62, K 17, Fem $\varnothing$, and WF 83.

\section{Antigens}

The antigens for immunization of rabbits were prepared from mucoid colonies obtained from 6-hour cultures on PPLO agar plates (Nicolet 1971). The growth was harvested in $0.9 \%$ saline with $1: 10.000$ merthiolate added, washed once at $4^{\circ} \mathrm{C}$ and resuspended in saline. The density of the suspension was adjusted to $9 \times 10^{5}$ organisms per $\mathrm{ml}$ by comparison with an opacity standard.

Antigen for tube agglutination tests was prepared from mucoid 6-hour cultures. The growth was harvested in phosphatebuffered saline (PBS) with 1:25.000 merthiolate added, washed once at $4^{\circ} \mathrm{C}$ and resuspended in PBS. The density of the suspension was adjusted to $6 \times 10^{5}$.

Antigens for the slide agglutination test were 6-hour old cultures on PPLO agar.

Saline washings for the indirect haemagglutination (IHA) test were obtained from 6-hour cultures. The growth was harvested in PBS with 1:20.000 merthiolate added and centrifuged at 5000 r.p.m. at $4^{\circ} \mathrm{C}$ for $15 \mathrm{~min}$.

Capsular extracts and ultrasonicated antigens were prepared as described earlier (Nielsen 1982).

\section{Antisera}

Rabbits were injected once intramuscularly in the thigh with $1 / 2 \mathrm{ml}$ antigen suspension mixed with equal parts of Freund's incomplete adjuvant. After 2 weeks, injections were given intravenously twice a week for appr. 6 weeks. The first injection was 
$0.2 \mathrm{ml}$ and the amount was raised by $0.2 \mathrm{ml}$ for each injection until the highest dose, $2 \mathrm{ml}$ was reached. This dose was repeated at least twice.

\section{Tube agglutination test}

Serial twofold dilutions of serum beginning at $1: 10$ were prepared in $0.9 \%$ saline with $0.5 \%$ phenol added. Equal amounts of antigen suspension $(0.4 \mathrm{ml})$ were added. The test was read after overnight incubation at $52^{\circ} \mathrm{C}$ in a water bath.

\section{IHA test}

The test was made as decribed earlier (Nielsen 1974).

\section{Gel diffusion test}

The medium consisted of $1 \%$ agar (Special agar Noble, Difco) in a $0.9 \%$ sodium chloride solution with $1 \%$ merthiolate in disposable petri dishes. Six wells, $4 \mathrm{~mm}$ in diameter, were punched in the agar at a distance of $6 \mathrm{~mm}$ from each other and from a central well. The plates were incubated at $37^{\circ} \mathrm{C}$ in a closed container with a relatively high humidity. Readings were made daily for 10 days.

\section{Absorption procedure}

For absorption of antisera the growth from 6 PPLO plates was harvested in PBS and centrifuged at 15.000 r.p.m. at $4^{\circ} \mathrm{C}$ for $15 \mathrm{~min}$. The sediment was used as absorbing antigen for $2 \mathrm{ml}$ antiserum. Each mixture of antigen and serum was slowly shaken at $37^{\circ} \mathrm{C}$ for $2 \mathrm{~h}$ and stored overnight at $4{ }^{\circ} \mathrm{C}$. After centrifugation at 15.000 r.p.m. for $15 \mathrm{~min}$ the absorption procedure was repeated once.

\section{Agglutination}

\section{RESULTS}

By the slide agglutination test none of the 8 strains revealed any serological relationship with serotypes 1 through 7 (Table1).

By tube agglutination and cross absorption tests the 8 strains proved identical (Table 2). None of the strains showed agglutination in antisera to serotypes 1 through 7 . 
T a b l e 1. Slide agglutination tests with 6-hour cultures of 6 Danish strains and 2 Irish strains against rabbit antisera prepared against 6hour cultures of strain 1265 , strain 405 and the type strains of serotypes 1 through 7 .

\begin{tabular}{|c|c|c|c|c|c|c|c|c|c|}
\hline \multirow[b]{2}{*}{ Antigen } & \multicolumn{9}{|c|}{ Antisera } \\
\hline & strain 1265 & strain 405 & $\begin{array}{c}\text { Sero- } \\
\text { type } \\
1 \\
4074 \\
\end{array}$ & $\begin{array}{c}\text { Sero- } \\
\text { type } \\
2 \\
1536 \\
\end{array}$ & $\begin{array}{c}\text { Sero- } \\
\text { type } \\
3 \\
1421 \\
\end{array}$ & $\begin{array}{c}\text { Sero- } \\
\text { type } \\
4 \\
\text { M } 62 \\
\end{array}$ & $\begin{array}{c}\text { Sero- } \\
\text { type } \\
5 \\
\text { K } 17 \\
\end{array}$ & $\begin{array}{c}\text { Sero- } \\
\text { type } \\
6 \\
\text { Fem } \emptyset\end{array}$ & 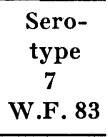 \\
\hline 1265 & + & + & - & - & - & - & - & - & - \\
\hline 405 & + & + & - & - & 一 & 一 & - & - & - \\
\hline 312 & + & + & 一 & - & 一 & - & - & - & - \\
\hline E.J. & + & + & - & - & - & - & - & - & - \\
\hline 84 & + & + & - & - & - & - & - & - & - \\
\hline 925 & + & + & - & - & - & - & - & - & - \\
\hline 9436 & + & + & - & - & - & - & - & - & - \\
\hline 13546 & + & + & - & - & - & - & - & - & - \\
\hline
\end{tabular}

$+=$ flocculation

$-=$ no flocculation

Table 2. Tube agglutination titers of rabbit antisera against H. pleuropneumoniae strains 405 and 1265 before and after absorption with strains 405 and 1265.

\begin{tabular}{|c|c|c|c|c|c|c|}
\hline \multirow[b]{3}{*}{ Antigen } & \multicolumn{3}{|c|}{ Antiserum 405} & \multicolumn{3}{|c|}{ Antiserum 1265} \\
\hline & \multirow[b]{2}{*}{ non absorbed } & \multicolumn{2}{|c|}{ absorbed with } & \multirow[b]{2}{*}{ non absorbed } & \multicolumn{2}{|c|}{ absorbed with } \\
\hline & & 405 & 1265 & & 405 & 1265 \\
\hline 405 & $640^{*}$ & - & - & 320 & - & - \\
\hline 1265 & 320 & - & - & 320 & - & - \\
\hline E.J. & 640 & - & - & 640 & - & - \\
\hline 84 & 640 & - & - & 640 & - & - \\
\hline 925 & 320 & - & - & 320 & - & - \\
\hline 9436 & 640 & - & - & 320 & - & - \\
\hline 13546 & 320 & 一 & - & 320 & 一 & - \\
\hline 312 & 640 & - & - & 320 & - & - \\
\hline
\end{tabular}

* Titers are given as reciprocais of the highest serum dilution giving flocculation

$-=$ no agglutination

\section{IHA test}

Sheep red cells sensitized with saline washings, capsule extract or sonicated antigen of the 8 strains were agglutinated to high titers by homologous antiserum. While no cross-reactions were observed between serotypes $1,2,3,4,5$ and 7 a serological 
relationship was revealed between strain Fem $\varnothing$ (serotype 6) and the 8 strains. An example is given in Table 3. Strain 405 antiserum showed homologous titers of $1: 1280$ to $1: 2560$ with the 3 antigen preparations. Cross-reactions were observed with antigens of strain Fem $\varnothing$. Also, strain Fem $\varnothing$ antiserum cross-reacted with antigens of strain 405. Heterologous titers were lower than homologous titers.

Homologous absorption removed all agglutinating activity from serum 405 whereas absorption with strain Fem $\varnothing$ removed only agglutinins for that strain. Homologous titers were not reduced (Table 3 ).

T a b l e 3. IHA titers obtained with various antigen preparations of strains 405 and Fem $\varnothing$ (serotype 6) against rabbit immune sera produced against whole-cell antigens. Sera were tested before and after homologous and heterologous absorption.

\begin{tabular}{|c|c|c|c|c|c|c|}
\hline \multirow[b]{2}{*}{ Antigen } & \multicolumn{3}{|c|}{ Antiserum } & \multicolumn{3}{|c|}{ Antiserum } \\
\hline & $\begin{array}{c}405 \\
\text { unabsorbed }\end{array}$ & $\begin{array}{l}\text { absorbe } \\
\text { with } \\
405\end{array}$ & $\begin{array}{l}\text { absorbed } \\
\text { with } \\
\text { Fem } \phi\end{array}$ & $\begin{array}{c}\text { Fem }{ }^{\text {al }} \\
\text { unabsorbed }\end{array}$ & $\begin{array}{l}\text { absorbed } \\
\text { with } \\
\text { d } 405\end{array}$ & $\begin{array}{l}\text { absorbed } \\
\text { with } \\
\text { Fem } \varnothing\end{array}$ \\
\hline 405 saline washings & 2560 & - & 2560 & 320 & - & - \\
\hline capsule extract & 1280 & - & 1280 & 40 & - & - \\
\hline sonicated antigen & 2560 & - & 2560 & 80 & - & - \\
\hline \multirow{3}{*}{$\begin{array}{c}\text { Fem } \varnothing \text { saline washings } \\
\text { capsule extract } \\
\text { sonicated antigen }\end{array}$} & 160 & - & - & 640 & 640 & - \\
\hline & 160 & - & - & 320 & 320 & - \\
\hline & 80 & - & - & 640 & 640 & - \\
\hline
\end{tabular}

Titers are given as reciprocals of the highest serum dilution giving positive reaction

$-=$ no reaction

Homologous absorption removed all agglutinins from serum Fem $\varnothing$ whereas absorption with strain 405 left homologous titers unreduced.

The results of the absorption experiments show that the capsular antigens of strain 405 and Fem $\varnothing$ are related, but not identical.

\section{Gel diffusion}

When saline washings of the 8 strains were used as antigen against antisera for strains 405 and 1265 and for serotypes 1 through 7, one homologous, serotype-specific precipitation line was seen. An example is given in Fig. 1, where strain 405 antigen 
is placed in the central well and antisera against serotypes 1,2 , 4, 5 and strain 405 are placed in the peripheral wells.

With capsule extract as antigen, 2 homologous, serotype specific precipitation lines were demonstrated: one sharp peripheral line and a fuzzier one close to the antigen well (Fig. 2). Comparative analyses of capsule extract and saline washings against homologous antiserum revealed a reaction of identity between the line formed by saline washings and the peripheral line formed by capsule extracts.

In addition to the homologous serotype-specific precipitates two pricipitation lines showing reaction of identity between all serotypes were seen (Figs. 1 and 2).

Comparative analyses of capsule extracts from strains 1421 (serotype 3), Fem $\varnothing$ (serotype 6), and 405 against antisera for strains 1421, Fem $\varnothing$ and 405 revealed a closer antigenic relationship between these strains. It was noted that, in addition to the 2

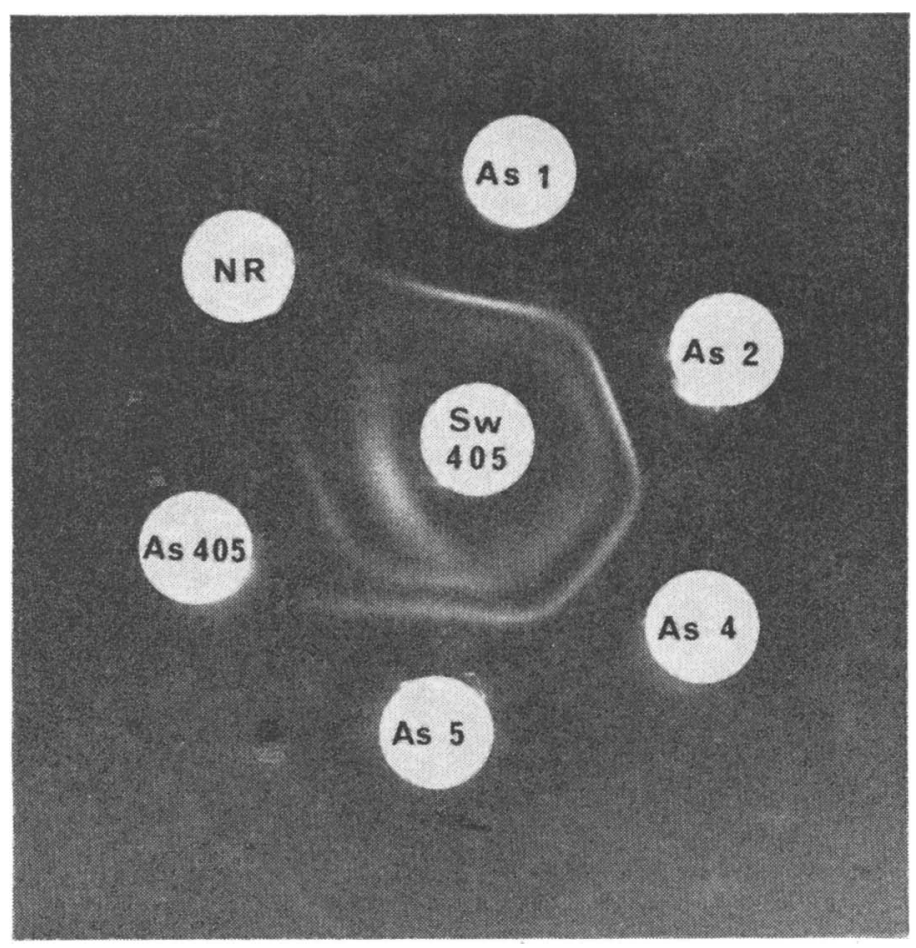

F i g u r e 1. Saline washings ( $\mathrm{Sw}$ ) of strain 405 in the center well. In the peripheral wells are antisera (AS) for serotypes 1, 2, 4, 5, strain 405 , and serum from a non-immunized rabbit (NR). 


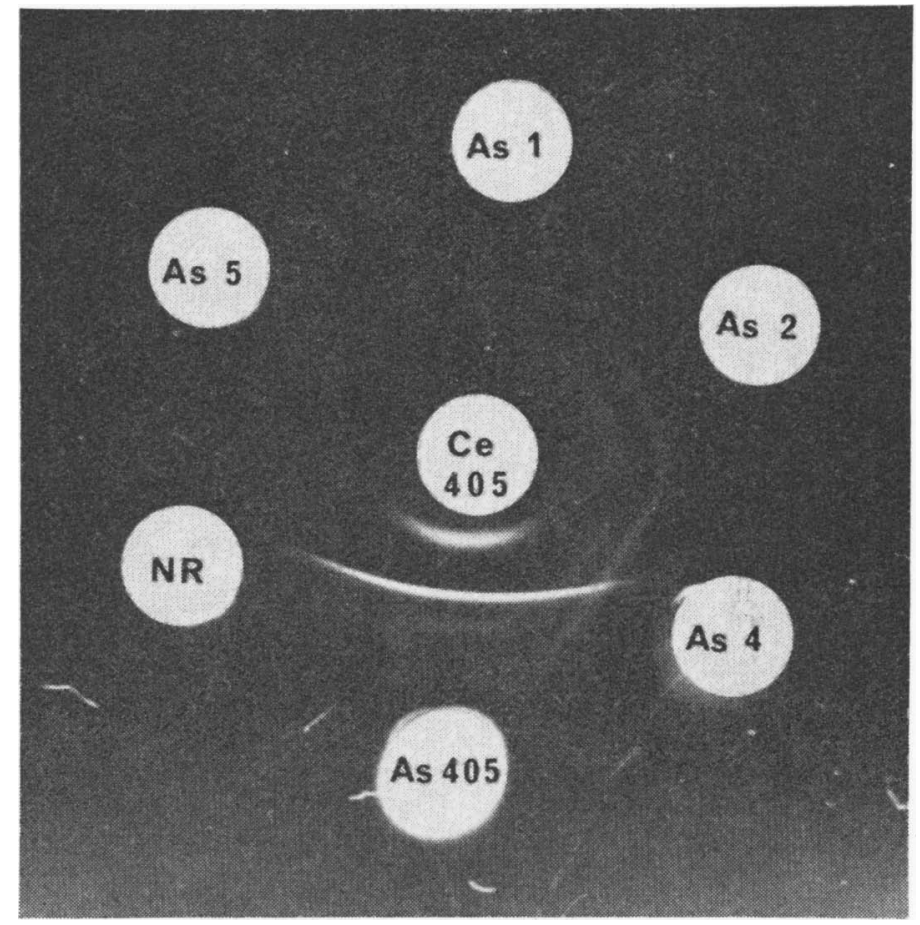

Figure 2. Capsule extract (Ce) of strain 405 in the center well. In the peripheral six wells are antisera (As) for serotypes 1, 2, 4, 5, strain 405, and serum from a non-immunized rabbit (NR).

capsular precipitinogens characteristic of the serotypes, capsular extracts of strains 405, 1421 and Fem $\varnothing$ also contained precipitinogens which reacted with antiserum for at least 1 of the other 2 serotypes. These precipitinogens were demonstrated as precipitation lines adjacent to the wells of the heterologous antigen preparations. Thus, with anti 405 a precipitation line was formed close to the 1421 (serotype 3 ) antigen well (Fig. 3). With anti 1421 one precipitation line was formed close to the 405 antigen well, another close to the Fem $\varnothing$ antigen well, and with serum Fem $\varnothing$ one line was formed at the 405 , another at the 1421 antigen well.

Absorptions of antisera 405, 1421 and Fem $\varnothing$ with their respective homologous antigen preparations resulted in complete removal of the homologous serotype specific precipitation lines.

Results obtained in cross-absorption studies indicated that in addition to serotype-specific capsular antigens strain 405 shared 


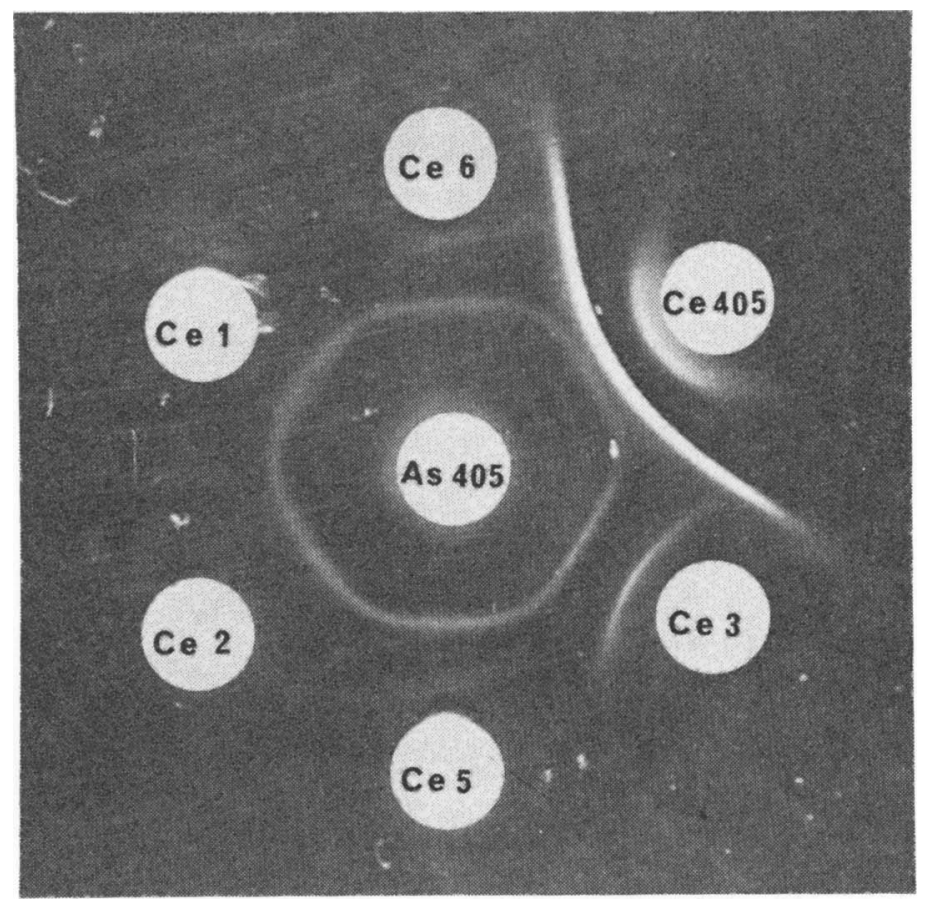

F i g u re 3. Rabbit antiserum (As) for strain 405 in the central well. In the peripheral wells are capsule extracts (Ce) of serotypes $1,2,3$, 5,6 and strain 405 .

capsular antigen with strain 1421 (serotype 3). Further, the results suggested the presence of common precipitinogens in the capsular extracts of strains 405, 1421 and Fem $\varnothing$.

Gel diffusion analyses involving the 7 other strains examined in this study gave the same results as those obtained with strain 405.

The heterologous precipitation lines described above for capsule extracts of strains 1421 , Fem $\varnothing$ and 405 were not seen in tests with saline washings of these strains or in tests with capsule extracts of serotypes 1, 2, 4, 5 and 7. This is illustrated in Fig. 3 where capsule extracts of serotypes 1,2 , and 5 is analysed against antiserum 405 .

\section{DISCUSSION}

By agglutination and immunodiffusion tests Nicolet (1971) and Gunnarsson (1980) showed that serotypes 1 through 5 of 
Haemophilus pleuropneumoniae possessed 2 type-specific antigens, both of which were af capsular origin. Common speciesspecific antigens were also demonstrated in all 5 serotypes.

The 8 strains $H$. pleuropneumoniae examined in the present study possessed 2 type-specific antigens of capsular origin as well as common species-specific antigens. As the 8 strains are antigenically homogenous and serologically distinct from other serotypes, we propose that these strains be referred to a new serotype, designated serotype 8 , with strain 405 as the type strain.

The results obtained with the IHA test and with the gel diffusion test suggested a closer relationship between serotypes 3,6 and 8 than between these serotypes and serotypes $1,2,4,5$ and 7 . The cross-reactions observed between serotypes 3,6 and 8 were shown by cross-absorption to be unrelated to type specificity.

The work of Keogh et al. (1948) gives evidence to suggest that, at least in some cases, polysaccharides are the active principles in the sensitization of erythrocytes to the agglutinating effect of immune sera. The results obtained wih the IHA test in the present investigation show that serotypes 6 and 8 share antigenic determinants which are part of the capsular substance and which are adsorbable to erytrocytes which are thereby rendered agglutinable by immune sera. This is consistent with a polysaccharide (PS) nature of these antigens. In contrast, the antigenic determinants shared by serotypes 3 and 8 were not adsorbable to erythrocytes and could be demonstrated only by gel diffusion tests. Heterologous precipitates were situated close to the antigen well concerned. In Haemophilus influenzae, type-specific capsular antigens have been characterized as PS (Branefors-Helander et al. 1976). A lipopolysaccharide (LPS) with type-specific as well as cross-reacting properties has been identified in capsules and on the cellular surface of $\mathrm{H}$. influenzae (Branefors-Helander 1973, Branefors-Helander et al. 1976). In immunodiffusion tests $H$. influenzae LPS precipitates are as a rule located closer to the antigen well than is usual for PS precipitates (Branefors-Helander 1973). Although until now nothing is known about the chemical structure of $\mathrm{H}$. pleuropneumoniae, the location of the precipitates observed in the present study suggests that the precipitinogens shared between serotypes 3 and 8 may be of LPS nature.

The presence of more than one capsular serotype in H. pleuropneumoniae has not been described earlier. However, the results 
obtained in this study are in accordance with the observations made by Branefors-Helander (1972) who in immunodiffusion studies of $\mathrm{H}$. influenzae found that the capsular antigen may carry more than one determinant and that more than one capsular serotype may be present in some strains.

Serotyping of field isolates of $\mathrm{H}$. pleuropneumoniae is important for rational prevention and control. Serotyping is based upon encapsulated cells. For routine laboratory diagnosis the slide agglutination test has proved valuable in charting out the serotypes existing in Danish swine herds (Nielsen 1982). In this study the slide agglutination test revealed that a hitherto unrecognized serotype existed. However, the slide and tube agglutination tests, using whole cells, failed to reveal the antigenic relationship between serotype 8 and serotypes 3 and 6 . The serotype specific capsular antigen seemed to mask the type 6 and 3 antigen components. The present study has indicated that the gel diffusion test and the indirect haemagglutination test are the methods of choice for further identification of unknown serotypes.

\section{ACKNOWLEDGEMENTS}

The very skilful technical assistance of Mrs. Tamara Plambeck is gratefully acknowledged.

\section{REFERENCES}

Biberstein, E. L., A. Gunnarsson \& B. Hurvell: Cultural and biochemical criteria for the identification of Haemophilus spp. from swine. Amer. J. vet. Res. 1977, 38, 7-11.

Branefors-Helander, P.: Serological studies of Haemophilus influenzae. I. Extracellular antigens of capsulated strains, types a to $\mathrm{f}$, and two non-capsulated variants. Int. Arch. Allergy 1972, 43, 533547.

Branefors-Helander, P.: Serological studies of Haemophilus influenzae. III. The endotoxic effect of various antigen preparations and the relation between this effect and demonstrable precipitinogens. Int. Arch. Allergy 1973, 44, 585-600.

Branefors-Helander, P., C. Erbing, L. Kenne \& B. Lindberg: Structural studies of the capsular antigen from Haemophilus influenzae type b. Acta chem. scand. Sect. B. 1976, 30, 276-277.

Gunnarsson, A., E. L. Biberstein \& B. Hurwell: Serologic studies on porcine strains of Haemophilus parahaemolyticus (pleuropneumoniae). Agglutination reactions. Amer. J. vet. Res. 1977, 38, 1111-1114.

Keogh, E. V., E. A. North \& M. F. Warburton: Adsorption of bacterial polysaccharides to erythrocytes. Nature $1948,161,687-688$. 
Kilian, M.: A taxonomic study of the genus Haemophilus with the proposal of a new species. Thesis, Århus 1976.

Nicolet, J.: Sur l'hemophilose du porc. III. Différenciation sérologique de Haemophilus parahaemolyticus (Haemophilus infections in pigs. III. Serological studies on Haemophilus parahaemolyticus). Zbl. Bakt. 1971, 216, 487-495.

Nielsen, R.: Serological and immunological studies of pleuropneumonia of swine caused by Haemophilus parahaemolyticus. Acta vet. scand. $1974,15,80-89$.

Nielsen, R.: Haemophilus pleuropneumoniae infection in pigs. Thesis 1982. Commissioned by C. F. Mortensen A/S, Bülowsvej $5 \mathrm{C}$, DK-1870 Copenhagen V, Denmark.

Rosendal, S. \& A. Boyd: Haemophilus pleuropneumoniae serotyping. J. clin. Microbiol. 1982, 16, 840-843.

\section{SAMMENDRAG}

Serologisk karakterisering af 8 Haemophilus pleuropneumoniae stammer og forelæggelse af en ny serotype, serotype 8.

Otte Haemophilus pleuropneumoniae stammer, isoleret fra 8 besætningsudbrud af pleuropneumoni, blev unders $\varnothing$ gt serologisk ved hjælp af objektglasagglutination, reagensglasagglutination, indirekte haemagglutination (IHA) og gel diffusion.

De 8 stammer udgjorde en homogen gruppe $i$ antigen henseende og var serologisk forskellige fra de hidtil kendte serotyper 1 til 7 . Gruppen er derfor blevet identificeret som en ny serotype, serotype 8 med stamme 405 som typestamme.

Ved hjælp af gel diffusion og IHA tests blev det påvist, at de 8 stammer, foruden serotype-specifikke kapselantigener, også indeholdt kapselantigener af serotype 3 (stamme 1421) og serotype 6 (stamme Fem $\varnothing$ ).

(Received February 23, 1984).

Reprints may be requested from: Ragnhild Nielsen, the State Veterinary Serum Laboratory, Bülowsvej 27, DK-1870 Copenhagen V, Denmark. 